\title{
Genetic Identification of Shiga Toxin Encoding Gene from Cases of Multidrug Resistance (MDR) Escherichia coli Isolated from Raw Milk
}

\author{
R. Ansharieta ${ }^{a}$, M. H. Effendi ${ }^{b, *}, \&$ H. Plumeriastuti ${ }^{c}$ \\ ${ }^{a}$ Master Program in Animal Diseases and Veterinary Public Health, Faculty of Veterinary Medicine, \\ Universitas Airlangga, \\ ${ }^{b}$ Department of Veterinary Public Health, Faculty of Veterinary Medicine, Universitas Airlangga, \\ 'Department of Veterinary Pathology, Faculty of Veterinary Medicine, Universitas Airlangga, \\ Surabaya, 60115, Indonesia \\ *Corresponding author: mheffendi@yahoo.com \\ (Received 29-03-2020; Revised 08-07-2020; Accepted 22-07-2020)
}

\begin{abstract}
Escherichia coli is one of bacteria which have resistant to three or more classes of antimicrobial agents. E. coli having resistant to three or more classes of antimicrobial drugs can be defined as multidrug-resistant (MDR) bacteria. The aim of the study was to evaluate the expression of Shiga toxin gen in MDR E. coli. A total of $\mathbf{2 5 0}$ raw milks samples were taken from dairy farms in Kediri, Probolinggo, Pasuruan, Blitar, and Batu Region, East Java Province, Indonesia. Each sample was cultured into enrichment media Brilliant Green Bile Lactose Broth and Eosin Methyllen blue agar, then identified with TSIA agar and IMVIC biochemistry test. Antibiotic sensitivity testing was done using KirbyBauer disc diffusion assay on medium Mueller-Hinton agar (Oxoid, CM0337). Antibiotics disks used were $30 \mu \mathrm{g}$ of Tetracycline (Oxoid, CT0054), $10 \mu \mathrm{g}$ of Streptomycin (Oxoid, CT0047), $30 \mu \mathrm{g}$ of Chloramphenicol (Oxoid, CT0013), $5 \mu \mathrm{g}$ of Trimethoprim (Oxoid, CT0057), and $30 \mu \mathrm{g}$ of Aztreonam (Oxoid, CT0264). Isolate showing resistance to at least 3 antibiotics disk were then continued with PCR assay to identify Shiga toxin E. coli (STEC) encoding st 2 gene. The study was designed to evaluate the nucleotide analysis of STEC gene. The result showed that $6.25 \%(1 / 16)$ of STEC encoding gene was found in MDR E. coli. This report of molecular identification on the presence of STEC gene in MDR E. coli confirmed a wider spread of MDR E. coli that can threaten animal health and human health.
\end{abstract}

Keywords: stx2 gene; MDR; Escherichia coli; raw milk; public health

\section{INTRODUCTION}

Escherichia coli which produces Shiga toxin (STEC), is defined as a group of $E$. coli which can produce a toxin called Shiga toxin (stx). There are two main types of Shiga toxins found in this STEC group. The two toxins are stx 1 and stx2 (Hunt, 2010). According to several reports of findings in the field, st $x 2$ type toxin is more common and more prevalent than stx1 toxin in E. coli isolates obtained from livestock feces (Tahamtan et al., 2010). Cattle are believed to be the main reservoir of the STEC bacteria (Hussein \& Sakuma, 2005). STEC is often identified with foodborne outbreaks throughout the world with mild symptoms such as mild diarrhea to severe symptoms such as hemolytic uremic syndrome (HUS) (Noris et al., 2012). Foods related to STEC infection are foods without cooking processes, such as raw meat, cheese, non-pasteurized milk or raw milk, fruit and vegetable juices, and other natural ingredients (Mohammadi et al., 2013).

Antimicrobial resistance is a global problem, in which scientific research has been carried out and indicates that this problem has a negative impact on human and animal health (Ventola, 2015). Irrational treatment and administration of antibiotics greater than the recommended dosage in agriculture increase the incidence of antimicrobial resistance in daily life, and this condition has a great impact on the social and economic aspects (Barriere, 2014). Antibiotic resistance makes health workers lose many antibiotic choices in the treatment of bacterial diseases, causing the high potential for treatment failure in cases of clinical complications (Llor \& Bjerrum, 2014). The applications of good hygiene and sanitation practices in animal farms are something that should be emphasized to prevent the distribution of MDR microbes in the populations and the transfer of MDR microbes from animals to humans.

Although antibiotic treatment is not the first choice in cases of infections caused by STEC, multidrugresistant (MDR) STEC is a public health problem that is quite dangerous because the strain acts as a reservoir of resistant genes (Cointe et al., 2018). MDR STEC bacteria can easily transfer the resistant genes to the other Enterobacteriaceae family bacteria in the body of living organisms or in the environment. Some bacteria 
in the gut of living organisms are friends and have the potential to transmit resistance genes to one another (Colavecchio et al., 2017). A number of researches have been conducted on STEC isolates from humans, but only a few have been identified from foodstuffs of animal origins. Report on the status of STEC bacterial resistance to antibiotics is also limited. Therefore, this study was conducted to identify the STEC gene, stx2, which is a prevalent form of MDR E. coli bacteria isolated from several dairy farms in East Java, Indonesia.

\section{MATERIALS AND METHODS}

The sample size in this study was 250 raw milk samples taken from the cow bulk milk of each dairy farm located in Kediri (K), Probolinggo (A), Pasuruan $(\mathrm{G})$, Blitar (S), and Batu $(\mathrm{H})$, East Java, Indonesia, during the period of September-December 2019. The study was conducted by purposive sampling with sample criteria of poor enclosure sanitation and dirty environment (Dairy, 2019). The number of farms calculated on average reached 1500-1800 lactation cows per location. Samples taken at each dairy farm location were 50 samples (cow bulk milk). A total of $25 \mathrm{~mL}$ of milk samples from each milk can be taken and placed in sterile plastics. Milk samples were put into a cool box at $4^{\circ} \mathrm{C}$ for transportation (Arya et al., 2012; Kristianingtiyas et al., 2020; Putra et al., 2019).

Each sample was cultured into enrichment media of Brilliant Green Bile Lactose Broth (Merck, 105454) and incubated at $37^{\circ} \mathrm{C}$ for $18-24$ hours. The positive results were characterized by the change of media from green to cloudy green color and the presence of gas in Durham tube (Effendi et al., 2019). The positive samples were then cultured in Eosin Methylene Blue (EMB) (Merck, 101347) and incubated at $37^{\circ} \mathrm{C}$ for $18-24$ hours (Putra et al., 2019). The colonies showing metallic green colors were purified and continued to the identification steps with Triple Sugar Iron Agar (TSIA) and IndolMotility, Methyl Red, Voges Proskauer, and Citrate (IMViC) tests. The positive samples were then stored in LB Broth (Himedia, M1245) for further use in the next testing.

Antibiotic sensitivity testing was done using Kirby-Bauer disc diffusion assay on MuellerHinton agar medium (Oxoid, CM0337). Antibiotics disks used were $30 \mu \mathrm{g}$ of Tetracycline (Oxoid, CT0054), $10 \mu \mathrm{g}$ of Streptomycin (Oxoid, CT0047), $30 \mu \mathrm{g}$ of Chloramphenicol (Oxoid, CT0013), $5 \mu \mathrm{g}$ of Trimethoprim (Oxoid, CT0057), and $30 \mu \mathrm{g}$ of Aztreonam (Oxoid, CT0264). Interpretation of results was con- ducted by measuring the diameter of the inhibitory zone formed, based on Clinical and Laboratory Standards Institutions, and the resistance to Aztreonam that is the monobactam can be referred as a presumptive extended spectrum beta lactamase (ESBL) (CLSI, 2018).

Isolate which shown resistance to at least 3 antibiotics disk was then taken from the LB Broth and transferred onto Nutrient Agar (Merck, 105450). The whole cell suspensions were made by mixing approximately 8-10 colonies from Nutrient Agar to $0.3 \mathrm{~mL}$ Tris- $\mathrm{HCl}$ containing EDTA (TE) buffer. The cell lysate was made by heating the suspension for $10 \mathrm{~min}$ with the boiling method. The lysates were centrifuged for $10 \mathrm{~min}$ at 8000 rpm to shed the cellular debris. A volume of $5 \mu \mathrm{L}$ of the supernatant was used as a template for amplification by PCR. The specific primer used in this study was st $x 2$ according to Brenjchi et al. (2011), F: 5'- CCA TGA CAA CGG ACA GCA GTT-3' and R: 5'- CCT GTC AAC TGA GCA CTT TG-3'.

Each PCR reaction was performed in a $25 \mu \mathrm{L}$ amplification mixture consisting of $2.5 \mu \mathrm{L} 10$ X PCR buffer (500 mM KCl, $200 \mathrm{mM}$ Tris $\mathrm{HCl}), 0.5 \mu \mathrm{L}$ dNTPs $(10$ $\mathrm{mM}), 1 \mu \mathrm{L} \mathrm{MgCl}$ (50 mM), $1.25 \mu \mathrm{L}$ of each primer $(0.5$ $\mu \mathrm{M}), 0.2 \mu \mathrm{L}$ of Taq DNA polymerase (5 unit/ $\mu \mathrm{L})$, and 2 $\mu \mathrm{L}$ of template. The thermocycler (Bio Rad, Hercules, CA) program was started with initial incubation at $94^{\circ} \mathrm{C}$ for $5 \mathrm{~min}$, followed by 35 cycles of denaturation at $94^{\circ} \mathrm{C}$ for $60 \mathrm{sec}$, annealing at $52^{\circ} \mathrm{C}$ for $30 \mathrm{sec}$ and elongation at $72^{\circ} \mathrm{C}$ for $60 \mathrm{sec}$, and a final extension at $72^{\circ} \mathrm{C}$ for $10 \mathrm{~min}$. The PCR products were separated by electrophoresis in $1.5 \%$ agarose gel at $100 \mathrm{~V}$ for $40 \mathrm{~min}$ in the tris-acetate buffer, visualized by ethidium bromide staining, illuminated by UV-transilluminator, and documented by a gel documentation apparatus. DNA ladder with $100 \mathrm{bp}$ was used as a marker for m-PCR assay. The expected size of products for stx 2 is $779 \mathrm{bp}$ (Brenjchi et al., 2011).

\section{RESULTS}

A total of 250 samples were taken from several dairy farms in East Java Province, Indonesia. E. coli isolates were found in 176 samples of fresh cow's milk. The E. coli isolates were then tested using Kirby Bauer disc diffusion assay with several antibiotics, namely Tetracycline, Streptomycin, Trimethoprim, Chloramphenicol, and Aztreonam. The number of isolates that were resistant to Tetracycline, Streptomycin, Trimethoprim, Chloramphenicol, and Aztreonam was $17.05 \%$ (30/176), 14.2\% (25/176), 9.66\% (17/176), $7.95 \%$ $(14 / 176)$, and $1.7 \%(3 / 176)$, respectively (Table 1$)$.

Table 1. Multidrug resistant Escherichia coli from raw cow's milk samples

\begin{tabular}{lcccc}
\hline Location & Sample Size & Confirmed E. coli & Multidrug resistant & Presumptive ESBL \\
\hline Kediri (K) & 50 & 35 & 3 & 0 \\
Probolinggo (A) & 50 & 36 & 2 & 0 \\
Pasuruan (G) & 50 & 30 & 4 & 1 \\
Blitar (S) & 50 & 38 & 1 & 2 \\
Batu (H) & 50 & 37 & 6 & 0 \\
Total & 250 & 176 & 16 & 3 \\
\hline
\end{tabular}

Note: Presumptive ESBL= presumptive extended spectrum beta lactamase. 
A total of 16 isolates were multidrug-resistant $E$. coli, and 3 isolates were isolates of presumptive ESBL producing E. coli. Seventeen isolates of MDR E. coli and presumptive ESBL that were evaluated in this study had patterns of resistance that were almost the same to the pattern of resistance to aminoglycoside class drug, i.e., Streptomycin (Table 2 and Figure 1).

After finding E. coli MDR isolates that were resistant to various antibiotics and presumptive ESBL producing $E$. coli, the presence of stx 2 gene was tested by PCR method. From 17 isolates tested by PCR, there was $1 E$. coli MDR isolates (5.88\%) that was found in the sample obtained from Probolinggo (Sample Code A-26), which showed a PCR product of stx2 gene at the size of $779 \mathrm{bp}$ (Figure 2). However, on Figures 3 and 4 there was no sample tested with a positive result of stx 2 gene.

\section{DISCUSSION}

Tetracycline has the highest resistance level because this antibiotic is used most often for dairy farming, followed by the other antibiotics such as those used in this study, namely the aminoglycoside (Streptomycin), macrolide (Chloramphenicol), and sulphonamide (Trimethoprim) groups (Hunter et al., 2010). The use of broad-spectrum antibiotics such as the tetracycline and beta-lactam classes are more common in clinical mastitis cases of dairy cows in Europe, due to their effective treatment results. For respiratory and digestive tract problems, the tetracycline and aminoglycoside groups are the first choice antibiotics, while the second choice is the macrolide group and the combination of sulfonamide-trimethoprim drugs, which have a significant

Table 2. Antimicrobial resistance of multidrug resistant (MDR) isolates

\begin{tabular}{|c|c|c|c|c|c|c|c|c|c|}
\hline \multirow{3}{*}{ No. } & \multirow{3}{*}{ Sample code } & \multicolumn{5}{|c|}{ Resistant to } & \multirow{3}{*}{$\begin{array}{l}\text { Multidrug } \\
\text { resistant } \\
(\mathrm{MDR})\end{array}$} & \multirow{3}{*}{$\begin{array}{l}\text { Presumptive } \\
\text { ESBL }\end{array}$} & \multirow{3}{*}{$\begin{array}{l}\text { Positive to } \\
\text { stx2 gene }\end{array}$} \\
\hline & & $\mathrm{TE}$ & $S$ & W & $\mathrm{C}$ & ATM & & & \\
\hline & & $30 \mu \mathrm{g}$ & $10 \mu \mathrm{g}$ & $5 \mu g$ & $30 \mu \mathrm{g}$ & $30 \mu g$ & & & \\
\hline 1. & K-03 & $\sqrt{ }$ & $\sqrt{ }$ & $\sqrt{ }$ & $\sqrt{ }$ & - & + & - & - \\
\hline 2. & K-04 & $\sqrt{ }$ & $\sqrt{ }$ & $\sqrt{ }$ & $\sqrt{ }$ & - & + & - & - \\
\hline 3. & $\mathrm{~K}-36$ & $\sqrt{ }$ & $\sqrt{ }$ & - & $\sqrt{ }$ & - & + & - & - \\
\hline 4. & A-26 & $\sqrt{ }$ & $\sqrt{ }$ & $\sqrt{ }$ & $\sqrt{ }$ & - & + & - & + \\
\hline 5. & A-44 & - & $\sqrt{ }$ & $\sqrt{ }$ & $\sqrt{ }$ & - & + & - & - \\
\hline 6. & G-12 & $\sqrt{ }$ & $\sqrt{ }$ & $\sqrt{ }$ & - & - & + & - & - \\
\hline 7. & G-31 & - & $\sqrt{ }$ & $\sqrt{ }$ & - & $\sqrt{ }$ & + & + & - \\
\hline 8. & G-35 & $\sqrt{ }$ & $\sqrt{ }$ & $\sqrt{ }$ & - & - & + & - & - \\
\hline 9. & $\mathrm{G}-43$ & $\sqrt{ }$ & $\sqrt{ }$ & - & $\sqrt{ }$ & - & + & - & - \\
\hline 10. & S-25 & $\sqrt{ }$ & - & - & $\sqrt{ }$ & $\sqrt{ }$ & + & + & - \\
\hline 11. & S-38 & - & $\sqrt{ }$ & - & - & $\sqrt{ }$ & - & + & - \\
\hline 12. & $\mathrm{H}-11$ & $\sqrt{ }$ & $\sqrt{ }$ & $\sqrt{ }$ & $\sqrt{ }$ & - & + & - & - \\
\hline 13. & H-15 & $\sqrt{ }$ & $\sqrt{ }$ & $\sqrt{ }$ & - & - & + & - & - \\
\hline 14. & H-28 & $\sqrt{ }$ & $\sqrt{ }$ & - & $\sqrt{ }$ & - & + & - & - \\
\hline 15. & $\mathrm{H}-37$ & $\sqrt{ }$ & $\sqrt{ }$ & - & $\sqrt{ }$ & - & + & - & - \\
\hline 16. & $\mathrm{H}-44$ & $\sqrt{ }$ & $\sqrt{ }$ & - & $\sqrt{ }$ & - & + & - & - \\
\hline 17. & H-45 & $\sqrt{ }$ & $\sqrt{ }$ & - & $\sqrt{ }$ & - & + & - & - \\
\hline
\end{tabular}

Note: TE= Tetracycline; $S=$ Streptomycin; $W=$ Trimethoprim; $C=$ Chloramphenicol; $A T M=$ Aztreonam; $\sqrt{ }=$ positive resistant. MDR is resistant to three or more classes; ESBL is resistant to ATM; presumptive ESBL= presumptive extended spectrum beta lactamase; Kediri (K), Probolinggo (A), Pasuruan (G), Blitar (S), and Batu (H); + = positive; - = negative.

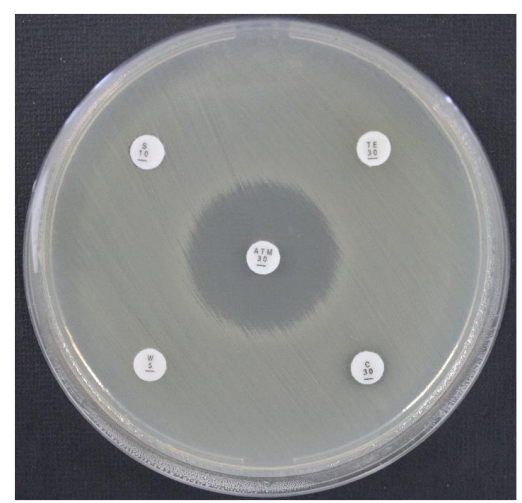

Figure 1. Multidrug resistant (MDR) Escherichia coli in KirbyBauer disk diffusion test

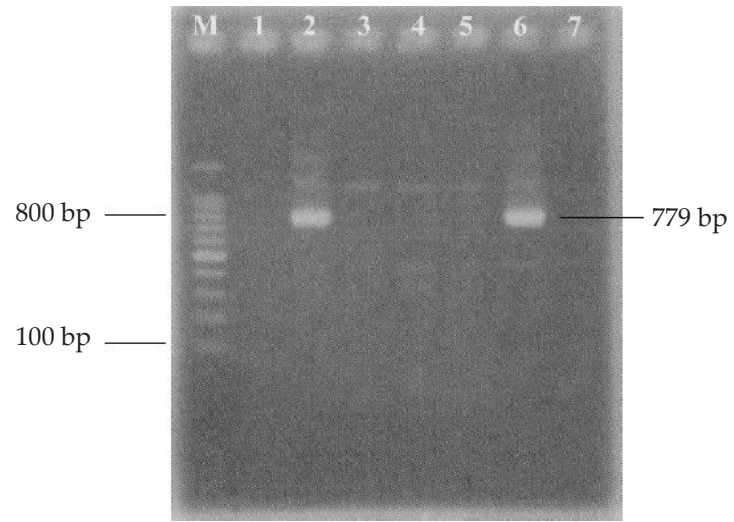

Figure 2. PCR analysis of stx2 gene on multidrug resistant (MDR) Escherichia coli from raw milk of cows; stx2 gene is indicated by the DNA band at $779 \mathrm{bp} . \mathrm{M}=$ marker 100 bp; $1=$ Negative Control; $2=$ Positive Control; $3=$ $\mathrm{K}-03 ; 4=\mathrm{K}-04 ; 5=\mathrm{K}-36 ; 6=\mathrm{A}-26 ; 7=\mathrm{A}-44$ 


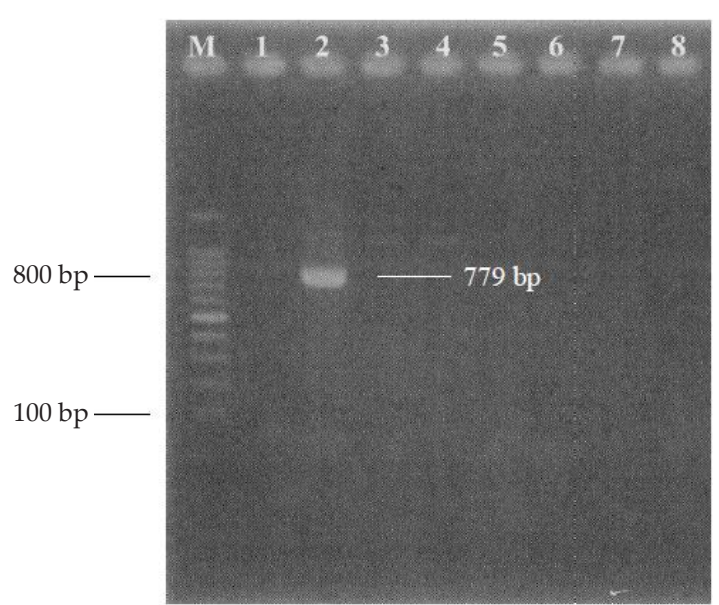

Figure 3. PCR analysis of stx2 gene on multidrug resistant (MDR) Escherichia coli from raw milk of cows; stx2 gene is indicated by the DNA band at $779 \mathrm{bp}$. M= marker 100 bp; $1=$ Negative Control; $2=$ Positive Control; $3=$ G-12; 4= G-31; 5= G-35; 6= G-43; 7= S- 25; 8= S-38.

impact on microbial activity in the rumen, and the last choice is the cephalosporin class three and four antibiotics (the sulfonamide-trimethoprim drug combination which has a significant impact on microbial activity in the rumen, and the last choice is the cephalosporin class three (Economou and Gousia, 2015).

This resistance to Streptomycin can be attributed to the effectiveness of the streptomycin drug in the treatment of mastitis in dairy cows in Indonesia. According to Riyanto et al. (2015), the administration of a combination of Penicillin-Streptomycin antibiotics is still considered as a good therapeutic treatment for dairy cows suffering from mastitis. Even though the level of resistance to the drug Streptomycin observed in this study is quite low $(14.2 \%)$, there is a need to monitor the use of antibiotics Streptomycin in dairy cows in Indonesia.

Chloramphenicol is not approved for use in food animals in Indonesia refer to Law No. 18 of 2009, concerning Animal Husbandry and Health. The persistence of chloramphenicol resistance in $E$. coli has been observed by the other authors (Tadesse et al. 2012), showing that more than $90 \%$ of chloramphenicolresistant E. coli isolates were concurrently resistant to tetracycline. In addition, Tadesse's data showed not only the persistence of chloramphenicol but an increasing trend of tetracycline resistance over time among animal E. coli isolates. These observations could be explained by co-selection of mobile resistance elements or by the unknown substrate(s) for the chloramphenicol-resistance determinants that serve as a selection pressure.

One method that is often used by various researchers to characterize organisms as Multidrug-Resistant (MDR) is based on the results of antimicrobial susceptibility testing in vitro, when researchers test resistance to several antimicrobial agents, classes or subclasses of antimicrobial agents (Kallen et al., 2010). MDR-organism is an organism that is resistant to three or more classes of antimicrobials (Magiorakos et al., 2012), or MDR is Gram-negative bacteria that are resistant to three

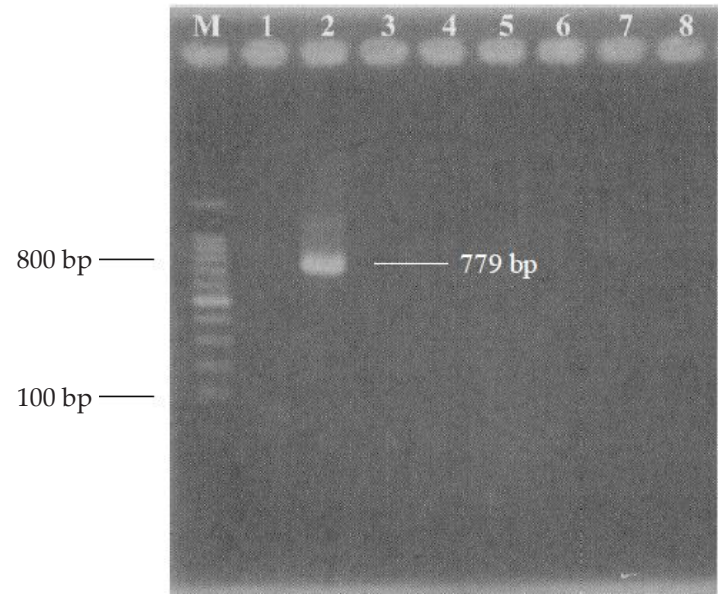

Figure 4. PCR analysis of stx2 gene on multidrug resistant (MDR) Escherichia coli from raw milk of cows; stx2 gene is indicated by the DNA band at 779 bp. $\mathrm{M}=$ marker 100 bp; $1=$ Negative Control; $2=$ Positive Control. Sample: $3=\mathrm{H}-11 ; 4=\mathrm{H}-15 ; 5=\mathrm{H}-28 ; 6=\mathrm{H}-37$; $7=\mathrm{H}-44 ; 8=\mathrm{H}-45$.

or more classes of antimicrobials (Gould, 2008), as is shown in Figure 1. A review of the variability of this definition is given in a comprehensive MDR review by Falagas et al. (2006), which is used as a reference by some researchers that a large number of studies do not propose specific definitions for MDR, as were shown in Table 2.

The literature shows that food-producing animals represent the most important source for the inclusion of STEC in the food chain. Most infections in humans are caused by the consumption of food contaminated with STEC. Food-producing animals are important reservoirs of STEC and function as sources of food contamination. Several studies found the presence of STEC, especially in fresh milk products and their processed products (Martin \& Beutin, 2011).

Shiga toxin-producing Escherichia coli (STEC) is a subgroup of Escherichia coli that are able to produce one or two strong toxins called Shiga 1 and Shiga 2 toxins (stx1 and st $x 2$ ), which are thought to have additional virulence factors such as intimin responsible for attaching STEC to the cells. Intestinal epithelium and causes the tight attachment and effect of lesions on the intestinal mucosa (Melton-Celsa, 2014). This bacterial pathotype is a causative agent of gastroenteritis and can be exacerbated by hemorrhagic colitis (HC) or hemolytic uremic syndrome (HUS), which is a major cause of acute kidney failure in children (Etcheverría \& Padola, 2013). Foodborne diseases related to STEC have been documented throughout the world. STEC serotype O157: H7 was reported as the causative agent of a series of outbreaks that were occurred mainly in Canada (Chui et al., 2011), Japan (Kanayama et al., 2013), the United States (Mc Collum et al., 2012), and the United Kingdom (Adams et al., 2016). In Indonesia, STEC was detected in feces $(8.3 \%)$ and meats $(5.3 \%)$, both isolated from cattle slaughtered in Qurban festival (Ningrum et al., 2016). In addition, from samples with positive STEC tested in the slaughterhouse in Surakarta, fifteen $E$ coli isolates were detected to contain stx2 gene (Goma et al., 2019). 
Observation of raw milk in Surabaya also detected two E. coli $(2.7 \%)$ having stx2 gene (Effendi et al., 2018).

One of the most debated topics in the management of STEC infections lies in the possible risks of using antibiotics in natural infections. Because antibiotics can lyse bacterial cell walls, then release Shiga toxin and cause an increase in Shiga toxin gene expression in vivo, generally antibiotics are not recommended for treating STEC infections (Paton \& Paton, 1998). Antibiotics have long been used in animal and human medical fields for the treatment, control, and prevention of infectious diseases. However, excessive use and not according to the rules of use can have unanticipated side effects, including the development of antibiotic resistance in bacteria against modern $\beta$-lactam antibiotics (Tekiner and Özpinar, 2016) or commonly known as an Extended Spectrum $\beta$-lactamase (ESBL). Although STEC infections are not treated aggressively with antibiotic therapy, there have been many STEC isolates that are susceptible to many antibiotics, and recent reports indicate that antimicrobial resistance from STEC also continues to increase (Ahmed \& Shimamoto, 2015).

Detection of STEC is labor-intensive and the total time required for strain characterization is usually 72 h. On the other hand, molecular methods are sensitive, specific, and a quick approach to detection and characterization of microbiological contaminants in food. The molecular characterization of STEC is performed by means of PCR. The study showed that among cases of MDR from E. coli samples, 5.88\% contained STEC encoding gene. Environmental contamination, herd management, and poor milking practices are important causes of milk degradation. It has been shown that food animals are important sources of STEC's entry into the food chain (Martin and Beutin, 2011).

The finding of STEC bacteria as contaminants from raw cow milk samples in this study can be considered as important and worthy results, referring to the study of Newell and La Ragione (2018), which states that with only small amounts, STEC colonies found in food samples of animal origin can cause digestive and urogenital disorders. For this reason, housing management and good sanitation practices during the process of milking cows, as well as their storage and distribution, should be improved even better so as to keep consumers away from foodborne diseases originating from raw cow's milk or other dairy products. Therefore, hygiene practices and strict management for dairy herds, processing, and storage of milk should be adopted to avoid undesirable illness due to contaminated milk, and it is important to encourage people to pasteurize milk for consumption.

\section{CONCLUSION}

Molecular identification showed that Shiga toxin encoding gene was found in raw cow milk from several regions with cases of Multidrug-Resistance (MDR) of Escherichia coli in East Java, Indonesia. These results show that raw cow's milk has a potential for spreading and poses a threat to public health from $E$. coli isolates.

\section{CONFLICT OF INTEREST}

The author states that there are no conflicts of interest with financial, personal, or other relationships with other people or organizations related to the material discussed in the manuscript.

\section{ACKNOWLEDGEMENT}

This study was supported in part with the Penelitian Hibah Mandat funding from Airlangga University, Indonesia in fiscal year 2019.

\section{REFERENCES}

Adams, N. L., L. Byrne, G. A. Smith, R. Elson, J. P. Harris, R. Salmon, R. Smith, S. J. O'Brien, G. K. Adak, \& C. Jenkins. 2016. Shiga toxin-producing Escherichia coli O157, England and Wales, 1983-2012. Emerg. Infect. Dis. 22 : 590-597. https://doi.org/10.3201/eid2204.151485

Ahmed, A. M. \& T. Shimamoto. 2015. Molecular analysis of multidrug resistance in Shiga toxin-producing Escherichia coli O157:H7 isolated from meat and dairy products. Int. J. Food Microbiol. 193: 68-73. https://doi.org/10.1016/j. ijfoodmicro.2014.10.014

Arya, R., B. Antonisamy, \& S. Kumar. 2012. Sample size estimation in prevalence studies. Indian J. Pediatr. 79: 1482-1488. https://doi.org/10.1007/s12098-012-0763-3

Barriere, S. L. 2014. Clinical, economic and societal impact of antibiotic resistance. Expert Opin. Pharmacother. 16: 151153. https://doi.org/10.1517/14656566.2015.983077

Brenjchi, M., A. Jamshidi, N. Farzaneh, \& MR.Bassami. 2011. Identification of Shiga toxin-producing Escherichia coli O157:H7 in raw milk samples from dairy farms in Mashhad using multiplex PCR assay. Iranian Journal of Veterinary Research. 12: 145-149.

Chui, L., M. C. Lee, K. Malejczyk, L. Lim, D. Fok, \& P. Kwong. 2011. Prevalence of Shiga toxin-producing Escherichia coli as Detected by Enzyme-Linked immunoassays and realtime PCR during the summer months in Northern Alberta, Canada. J. Clin. Microbiol. 49: 4307-4310. https://doi. org/10.1128/JCM.05211-11

CLSI. 2018. M100 Performance Standards for Antimicrobial Susceptibility Testing. $28^{\text {th }}$ ed. Clinical and Laboratory Standards Institute, USA.

Cointe, A., A. Birgy, P. Mariani-Kurkdjian, S. Liguori, C. Courroux, J. Blanco, S. Delannoy, P. Fach, E. Loukiadis, P. Bidet, \& S. Bonacorsi. 2018. Emerging multidrug-resistant hybrid pathotype Shiga toxin-producing Escherichia coli O80 and related strains of clonal complex 165, Europe. Emerg. Infect. Dis. 24: 2262-2269. https://doi.org/10.3201/ eid2412.180272

Colavecchio, A., B. Cadieux, A. Lo, \& L. D. Goodridge. 2017. Bacteriophages contribute to the spread of antibiotic resistance genes among foodborne pathogens of the Enterobacteriaceae family - A Review. Front. Microbiol. 8: 1108. https://doi.org/10.3389/fmicb.2017.01108

Dairy, N. Z. 2019. Dairy Cow Housing-A Good Practice Guide for Dairy Housing in New Zealand, Version 2. DairyNZ and Ministry for Primary Industries, Hamilton, New Zealand.

Economou, V. \& P. Gousia. 2015. Agriculture and Food Animals as A Source of Antimicrobial-Resistant Bacteria. Infect. Drug Resist. 8: 49-61. https://doi.org/10.2147/IDR.S55778

Effendi, M. H., N. Harijani, S. M. Yanestria, \& P. Hastutiek. 2018. Identification of Shiga toxin-producing Escherichia coli in raw milk samples from dairy cows in Surabaya, 
Indonesia. Philipp. J. Vet. Med. 55: 109-114.

Effendi, M. H., N. Harijani, Budiarto, N. P. Triningtya, W. Tyasningsih, \& H. Plumeriastuti. 2019. Prevalence of pathogenic Escherichia coli isolated from subclinical mastitis in East Java Province, Indonesia. Indian Vet. J. 96: 22-25.

Etcheverría A. I. \& N. L. Padola. 2013. Shiga toxin-producing Escherichia coli, factors involved in virulence and cattle colonization. Virulence 4: 366-372. https://doi.org/10.4161/ viru. 24642

Falagas, M.E., P.K. Koletsi, \& I. A. Bliziotis. 2006. The diversity of definitions of multidrug-resistant (MDR) and pandrugresistant (PDR) Acinetobacter baumannii and Pseudomonas aeruginosa. J. Med. Microbiol. 55: 1619-1629. https://doi. org/10.1099/jmm.0.46747-0

Goma, MKE, A. Indraswari, A. Haryanto, \& D.A. Widiasih. 2019. Detection of Escherichia coli O157:H7 and Shiga toxin 2a gene in pork, pig feces, and clean water at Jagalan slaughterhouse in Surakarta, Central Java Province, Indonesia, Vet. World, 12(10): 1584-1590. https://doi. org/10.14202/vetworld.2019.1584-1590

Gould, I. M. 2008. The epidemiology of antibiotic resistance. Int. J. Antimicrob. Agents. 32: 2-9. https://doi.org/10.1016/j. ijantimicag.2008.06.016

Hunt, J. M. 2010. Shiga toxin-producing Escherichia coli (STEC). Clin. Lab. Med. 30: 21-45. https://doi.org/10.1016/j. cll.2009.11.001

Hunter, P. A., S. Dawson, G. L. French, H. Goossens, P. M. Hawkey, E. J. Kuijper, D. Nathwani, D. J. Taylor, C. J. Teale, R. E., Warren, M. H. Wilcox, N. Woodford, M. W. Wulf, \& L. J. Piddock. 2010. Antimicrobial-resistant pathogens in animals and man: Prescribing, Practices and Policies. J. Antimicrob. Chemother. 65: i3-i17. https://doi. org/10.1093/jac/dkp433

Hussein, H. S. \& T. Sakuma. 2005. Invited Review: Prevalence of Shiga Toxin-producing Escherichia coli in dairy cattle and their products. J. Dairy Sci. 88: 450-465. https://doi. org/10.3168/jds.S0022-0302(05)72706-5

Kallen, A. J., A. I. Hidron, J. Patel, \& N. A. Srinivasa. 2010. Multidrug resistance among gram-negative pathogens that caused healthcare-associated infections reported to The National Healthcare Safety Network, 2006-2008. Infect. Control Hosp. Epidemiol. 31: 528-531. https://doi. org/10.1086/652152

Kanayama, A., Y. Yahata, Y. Arima, T. Takahashi, T. Saitoh, K. Kanou, K. Kawabata, T. Sunagawa, T. Matsui, \& K. Oishi. 2015. Enterohemorrhagic Escherichia coli outbreaks related to childcare facilities in Japan, 2010-2013. BMC Infectious Diseases. 15: 539. https:/doi.org/10.1186/ s12879-015-1259-3

Kristianingtyas, L., M. H. Effendi, W. Tyasningsih, \& F. Kurniawan. 2020. Genetic identification of blactx-M gene and blatem gene on extended spectrum beta lactamase (ESBL) producing Escherichia Coli from Dogs. Indian Vet. J. 97:01:17-21.

Llor, C. \& L. Bjerrum. 2014. Antimicrobial resistance: risk associated with antibiotic overuse and initiatives to reduce the problem. Ther. Adv. Drug Saf. 5: 229-241. https://doi. org/10.1177/2042098614554919

Magiorakos, A. P., A. Srinivasan, R. B. Carey, Y. Carmeli, M. E. Falagas, C. G. Giske, S. Harbarth, J. F. Hindler, G. Kahlmeter, B. Olsson-Liljequist, D. L. Paterson, L. B. Rice, J. Stelling, M. J. Struelens, A. Vatopoulos, J. T. Weber, \& D. L. Monnet. 2012. Multidrug-resistant, extensively drug-resistant and pandrug-resistant bacteria: An international expert proposal for interim standard definitions for acquired resistance. Clin. Microbiol. Infect. 18: 268-281. https://doi.org/10.1111/j.1469-0691.2011.03570.x
Martin, A. \& L. Beutin. 2011. Characteristics of Shiga toxin-producing Escherichia coli from meat and milk products of different origins and association with food producing animals as main contamination sources. Int. J. Food Microbiol. 146: 99-104. https://doi.org/10.1016/j.ijfoodmicro.2011.01.041

Mc Collum, J. T., N. J. Williams, S. W. Beam, S. Cosgrove, P. J. Ettestad, T. S. Ghosh, A. C. Kimura, L. Nguyen, S. G. Stroika, R. L. Vogt, A. K. Watkins, J. R. Weiss, I. T. Williams, \& A. B. Cronquist. 2012. Multistate outbreak of Escherichia coli O157:H7 infections associated with instore sampling of an aged raw-milk Gouda cheese. J. Food Prot. 75: 1759-1765. https://doi.org/10.4315/0362-028X. JFP-12-136

Melton-Celsa, A. R. 2014. Shiga Toxin (Stx) classification, structure and function. Microbiol. Spectr. 2: EHEC-0024-2013. https:/doi.org/10.1128/microbiolspec.EHEC-0024-2013

Mohammadi, P., R. Abiri, M. Rezaei, \& S. SalmanzadehAhrabi. 2013. Isolation of Shiga toxin-producing Escherichia coli from raw milk in Kermanshah, Iran. Iran. J. Microbiol. 5: 233-238.

Newell, D. G. \& R. M. La Ragione. 2018. Enterohaemorrhagic and other Shiga toxin-producing Escherichia coli (STEC): where are we now regarding diagnostics and control strategies?. Transbound. Emerg. Dis. 65: 49-71. https://doi. org/10.1111/tbed.12789

Ningrum, S. G., R. D. Soejoedono, H. Latif, W. Arnafia, \& I. W. T. Wibawan. 2016. Prevalence and characterization of Shiga toxin-producing Escherichia coli isolated from slaughtered qurban animal in Jakarta Province. Med. Pet., 39: 90-94. https://doi.org/10.5398/medpet.2016.39.2.90

Noris, M., F. Mescia, \& G. Remuzzi. 2012. STEC-HUS, Atypical HUS and TTP are all diseases of complement activation. Nat. Rev. Nephrol. 8: 622-633. https://doi.org/10.1038/ nrneph.2012.195

Paton J. C. \& A. W. Paton. 1998. Pathogenesis and diagnosis of Shiga toxin-producing Escherichia coli infections. Clin. Microbiol. Rev. 11: 450-479. https://doi.org/10.1128/ CMR.11.3.450

Putra, A. R. S., M. H. Effendi, S. Koesdarto, \& W. Tyasningsih. 2019. Molecular identification of Extended Spectrum BetaLactamase (ESBL) producing Escherichia coli isolated from dairy cows in East Java Province, Indonesia. Indian Vet. J. 96: 26-30.

Riyanto, J., Sunarto, B. S. Hertanto, M. Cahyadi, R. Hidayah, \& W. Sejati. 2016. Produksi dan kualitas susu sapi perah penderita mastitis yang mendapat pengobatan antibiotik. Sains Peternak. 14: 30-41. https://doi.org/10.20961/ sainspet.14.2.30-41

Tadesse, D. A., S. Zhao, E. Tong, S. Ayers, A. Singh, M.J. Bartholomew, and P.F. McDermott. 2012. Antimicrobial drug resistance in Escherichia coli from humans and food animals, United States, 1950-2002. Emerging Infectious Diseases. 18: 741-749. https://doi.org/10.3201/ eid1805.111153

Tahamtan, Y., M. Hayati, \& M. Namavari. 2010. Prevalence and distribution of the stx1, stx2 genes in Shiga toxin producing E. coli (STEC) isolates from cattle. Iran. J. Microbiol. 2: 8-13.

Tekiner, I. H. \& H. Özpinar. 2016. Occurrence and characteristics of extended spectrum Beta-Lactamases-producing Enterobacteriaceae from foods of animal origin. Braz. J. Microbiol. 47: 444-451. https://doi.org/10.1016/j. bjm.2015.11.034

Ventola, C. L. 2015. The antibiotic resistance crisis: part 1: causes and threats. Pharm. Ther. 40: 277-283. 